\title{
Early Ordovician conodonts from the Santa Rosita Formation at Pantipampa, Iruya area, northwestern Argentina
}

\author{
*Josefina Carlorosi ${ }^{1}$, Susana B. Esteban ${ }^{2}$, M. Franco Tortello ${ }^{3}$
}

\author{
Instituto Superior de Correlación Geológica (INSUGEO)- Consejo Nacional de Investigaciones Científicas y Técnicas (CONICET), \\ Miguel Lillo 205, (4000) Tucumán, Argentina. \\ 2 Instituto Superior de Correlación Geológica, Facultad de Ciencias Naturales e Instituto Miguel Lillo, Universidad Nacional de \\ Tucumán, Miguel Lillo 205, 4000 San Miguel de Tucumán, Argentina. \\ susanabesteban@hotmail.com \\ 3 Consejo Nacional de Investigaciones Científicas y Técnicas, Universidad Nacional de La Plata, División Paleozoología Invertebrados, \\ Museo de La Plata, Paseo del Bosque s/n, 1900 La Plata, Argentina. \\ tortello@fcnym.unlp.edu.ar \\ * Corresponding author: josefinacarlorosi77@gmail.com.
}

\begin{abstract}
A conodont assemblage recovered from the middle part of the Santa Rosita Formation at Pantipampa (Iruya area, northwestern Argentina) is described herein. It includes Cordylodus angulatus Pander, C. cayesi Druce and Jones, C. lindstromi Druce and Jones, C. hastatus Barnes, Furnishina furnishi Müller, Kallidontus gondwanicus Zeballo and Albanesi, Phakelodus elongatus An, Phakelodus tenuis (Zhang), Proconodontus muelleri Miller, Semiacontiodus sp. and Teridontus nakamurai Nogami, which are characteristic of the Cordylodus angulatus Zone (upper lower Tremadocian). In the Iruya area, the $C$. angulatus Zone correlates with the trilobite Kainella meridionalis Zone and the lower part of the Kainella teiichii Zone. Taxonomic diversity and relative frequency of conodont species enables the recognition of the Semiacontiodus-Teridontus community, which is characteristic of shallow marine environments.
\end{abstract}

Keywords: Conodonts, Tremadocian, Santa Rosita Formation, Iruya, Argentina.

RESUMEN. Conodontes del Ordovícico temprano de la Formación Santa Rosita en Pantipampa, área de Iruya, Noroeste Argentino. La asociación de conodontes recuperada de la parte media de la Formación Santa Rosita en Pantipampa (área de Iruya, noroeste de Argentina), descrita en este trabajo, se encuentra integrada por: Cordylodus angulatus Pander, C. cayesi Druce y Jones, C. lindstromi Druce y Jones, C. hastatus Barnes, Furnishina furnishi Müller, Kallidontus gondwanicus Zeballo y Albanesi, Phakelodus elongatus An, Phakelodus tenuis (Zhang), Proconodontus muelleri Miller, Semiacontiodus sp. y Teridontus nakamurai Nogami; estas especies son características de la Zona de Cordylodus angulatus (Tremadociano inferior alto). En el área de Iruya, la Zona de C. angulatus se correlaciona con la Zona de trilobites Kainella meridionalis y la parte inferior de la Zona de Kainella teiichii. La diversidad taxonómica y la frecuencia relativa de las especies de conodontes permiten el reconocimiento de la biofacies Semiacontiodus-Teridontus, que es característica de ambientes marinos poco profundos. 


\section{Introduction}

The Cordillera Oriental, northwestern Argentina (Fig. 1A and B) is characterized by large thrust belts of lower Paleozoic rocks that include late Furongianlate Tremadocian highly fossiliferous sandstone and shale of the Santa Rosita Formation (Turner, 1960) (Fig. 1C). Trilobites, graptolites and conodonts of this formation led to a biostratigraphic chart which, since the original proposal of Harrington and Leanza (1957), has constantly been improving (e.g., Ortega and Albanesi, 2005; Albanesi et al., 2008; Waisfeld and Vaccari, 2008; Vaccari et al., 2010; Zeballo and Albanesi, 2013).

Biostratigraphically well-constrained Tremadocian fossil sites include the Santa Victoria, Nazareno, El Perchel, Tilcara and Purmamarca areas (Fig. 1B).

In addition, Tortello and Esteban (2016) recently described a Tremadocian succession from the Pantipampa locality (Iruya area, Salta Province)
(Fig. 1C) in which the trilobite Kainella meridionalis and $K$. teiichii zones are well exposed. Trilobites are abundant throughout this succession, whereas graptolites (Rhabdinopora Eichwald, 1855) and conodonts were reported only from the lower and middle parts of the section, respectively. The aims of this paper are to describe in detail the conodont faunas from the Santa Rosita Formation at Pantipampa, and to refine the age assignment and correlations with other Lower Ordovician localities from the Cordillera Oriental and the world.

\section{Geological setting}

The Cordillera Oriental is a high relief thrust system that is delimited to the east by the Sierras Subandinas and to the west by the Puna (Fig. 1B). Lower Paleozoic rocks are well represented in the mountain ranges of this geological province, including Cambrian quartzite of the Mesón Group and late Furongian-Early Ordovician shales and sandstones of the Santa Victoria Group (Santa Rosita and Acoite

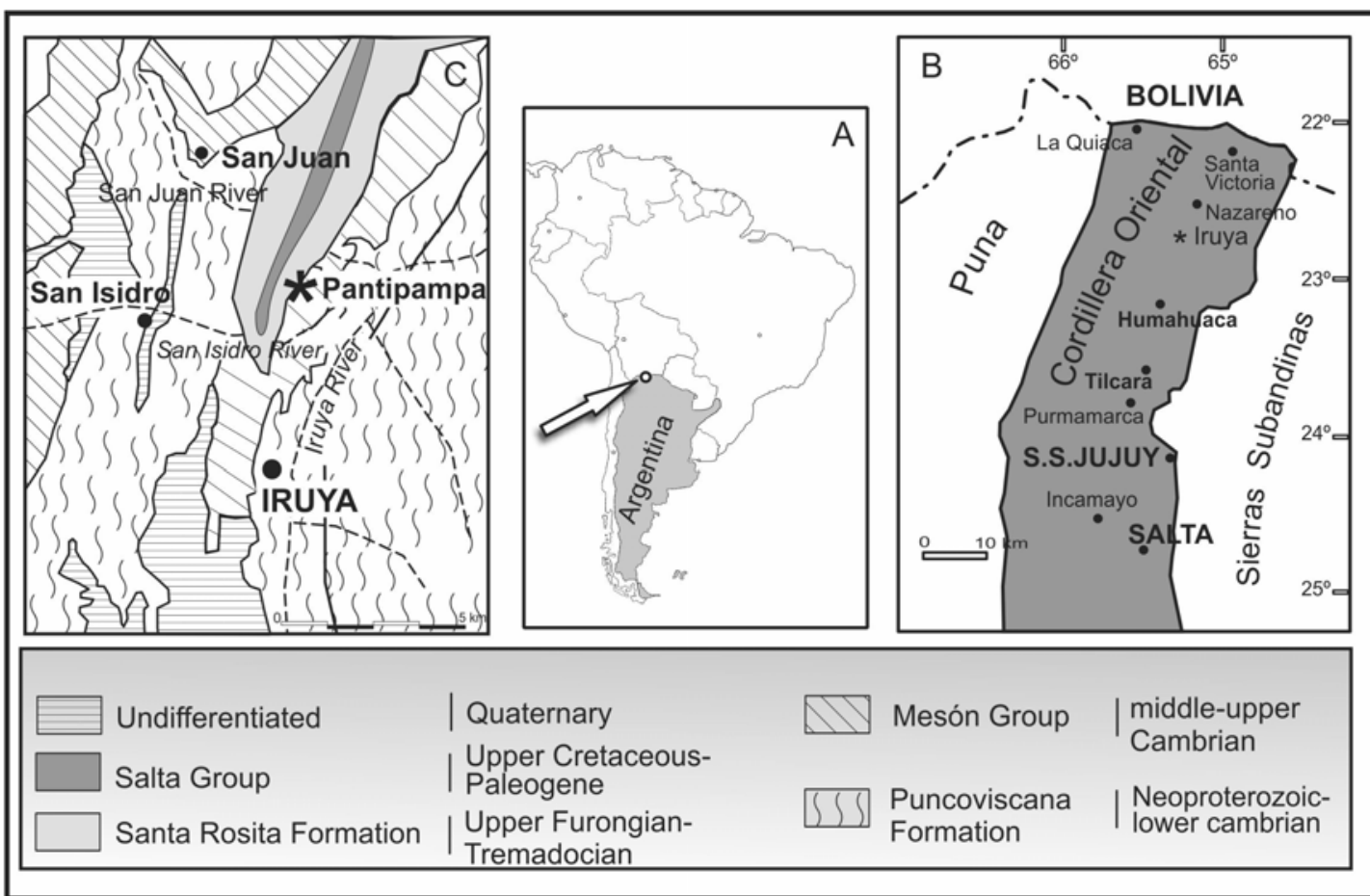

FIG. 1. Location map (A and B) and geologic framework of the Iruya area, northwestern Argentina (C), with the location (asterisk) of the Pantipampa locality (after Figueroa Caprini, 1955; Vilela, 1960; Turner, 1964; Astini, 2003). The Santa Rosita Formation is in ligth gray (Modified from Tortello and Esteban, 2016). 
formations and equivalents), which are juxtaposed on Neoproterozoic-early Cambrian slates and metagraywackes of the Puncoviscana Formation (e.g., Harrington and Leanza, 1957; Turner, 1960; Turner and Mon, 1979; Moya, 1988, 1999; Ramos, 1999, 2008; Astini, 2003). The Santa Rosita Formation (upper Furongian-Tremadocian) is highly fossiliferous and includes an extensive range of sedimentary facies (Buatois and Mángano, 2003; Moya et al., 2003; Buatois et al., 2006; Esteban et al., 2016).
The Pantipampa locality is about $5 \mathrm{~km}$ north of Iruya town (Iruya Department, Salta Province) (Fig. 1C). There, shale and sandstone of the Santa Rosita Formation constitute narrow thrust belts (in ligth grey in figure 1C) which unconformably overlie the Cambrian quartzite of the Mesón Group (Turner, 1960), and are unconformably overlain by the Upper Cretaceous-Paleogene continental sandstone of the Salta Group (Turner, 1959) and Quaternary alluvial deposits (Turner, 1964; Figueroa Caprini, 1955;

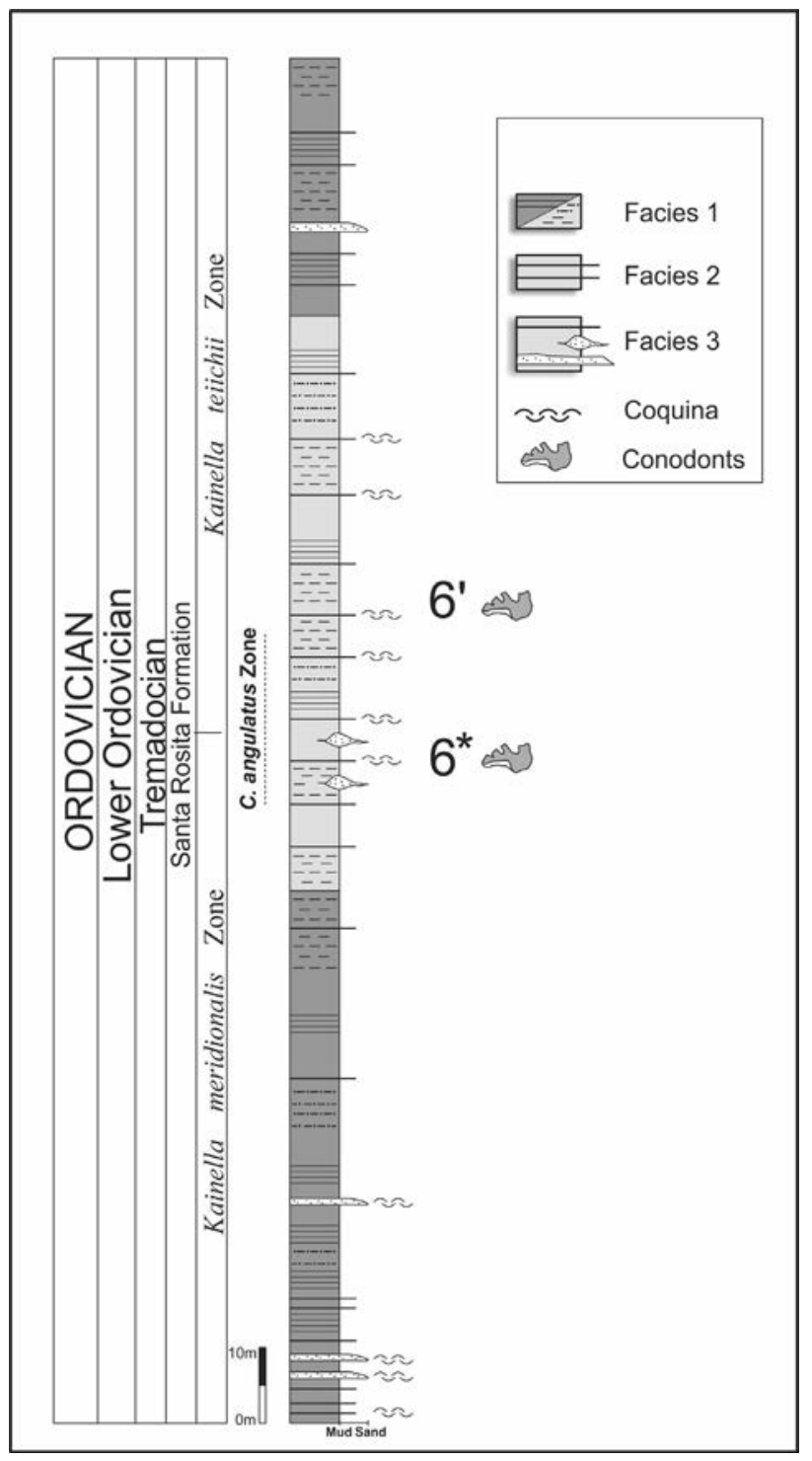

FIG. 2. Stratigraphic section of the middle part of the Santa Rosita Formation at Pantipampa (Iruya area, northwestern Argentina) displaying facies succession and provenance of conodont samples (6' and 6*; based on Tortello and Esteban, 2016). 


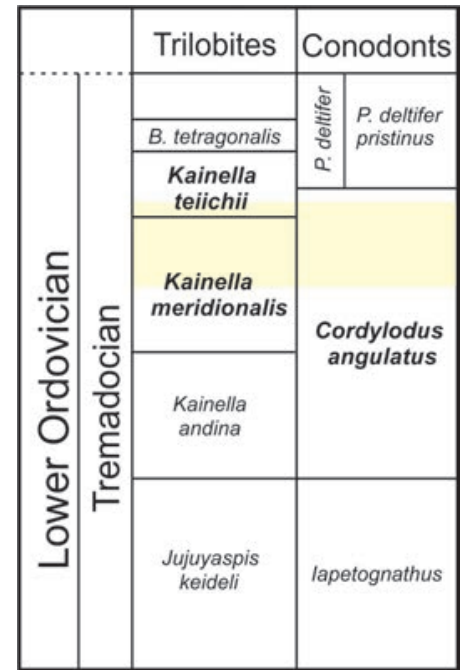

FIG. 3. Correlation chart of the Lower and Middle Tremadocian trilobite and conodont zones of northwestern Argentina. The interval studied in this paper is highlighted (modified from Tortello and Esteban, 2016).

Vilela, 1960; Turner and Mon, 1979). As stated above, Tortello and Esteban (2016) described a stratigraphic section from Pantipampa containing high-diversity trilobite assemblages of the Kainella meridionalis and $K$. teiichii zones (upper lower Tremadocian) (Figs. 2 and 3).

The Pantipampa section is interpreted as having formed in a wave-dominated shelf with influence of storm activity (Tortello and Esteban, 2016; Esteban et al., 2017). Three sedimentary facies are recognized throughout the succession. Facies 1 is characterized by dark and greenish gray, massive to thinly laminated shale, mudstone and silty mudstone, which are irregularly interbedded with gray, massive, very fine-grained silty sandstone in sharp-based, tabular beds $1-3 \mathrm{~cm}$ thick (Facies 2). Many trilobites were collected from Facies 1, in association with brachiopods, gastropods, bivalves, cephalopods and echinoderms. Dark gray to greenish gray, fine to very fine sandstone and calcareous sandstone beds containing bioclastic concentrations characterize Facies 3. Bioclastic concentrations consist mainly of fragmented brachiopods and trilobites, and generally appear at the bases of the calcareous sandstone beds, constituting lenses and layers up to $4 \mathrm{~cm}$ thick. Occasionally, concentrations occur at the tops of the sandstone beds. These beds were sampled for conodonts and two levels have produced positive results (Fig. 2).

\section{Material and methods}

A total of 882 conodonts were obtained from the Santa Rosita Formation in the Pantipampa locality. The samples were processed in the INSUGEO laboratory by using standard acid etching techniques (Stone, 1987). The conodonts were photographed with scanning electron microscopes of CCT-Mendoza and CIME-Tucumán (Argentina). Specimens are in the Collection Lillo-microvertebrates/Conodonts of the Instituto Superior de Correlación Geológica -INSUGEO (CONICET-Universidad Nacional de Tucumán), under the code MLC-C (20002882).

The assemblage studied comprises paraconodonts and euconodonts (Figs 4-5). Although the faunal diversity is low, the identified species are biostratigraphically significant.

The cordylodontid elements are well preserved, showing entire cusps and denticles with visible white matter, and a Color Alteration Index (CAI) degree of $1^{\circ}-1.5^{\circ}$ (Epstein et al., 1977). These elements are regarded as autochthonous and therefore provides essential information about the age of the assemblage.

On the other hand, simple cone elements (para and protoconodonts) show clear indications of abrasion (Fig. 5.L-O, Q) and high CAI values $\left(4^{\circ}-5^{\circ}\right)$, so they may have been redeposited from older strata. Conodont-bearing sediments of the studied section were deposited in moderately high-energy conditions above storm wave base, in a favourable environment for conodont element reworking (e.g., Löfgren et al., 2005; Viira et al., 2006). Other taphonomic processes that affected the cone elements include partial dissolution of the basal margins and walls, as well as basal filling and mineral coating. The walls of some elements show small circular holes, which may have been produced by bioerosion.

The high CAI values of the simple cones could be attributed to the presence of a high carbon content which may have been transferred to the elements from the dark, organic-rich carbonate sandstone in which they were originally preserved; therefore, the CAI of these cones would not reflect the thermal history of the rocks that contain them (Epstein et al., 1977; Rejebian et al., 1987; Nowlan and Barnes, 1987). In addition, these high CAI values could be partially explained by the effect of lithostatic 


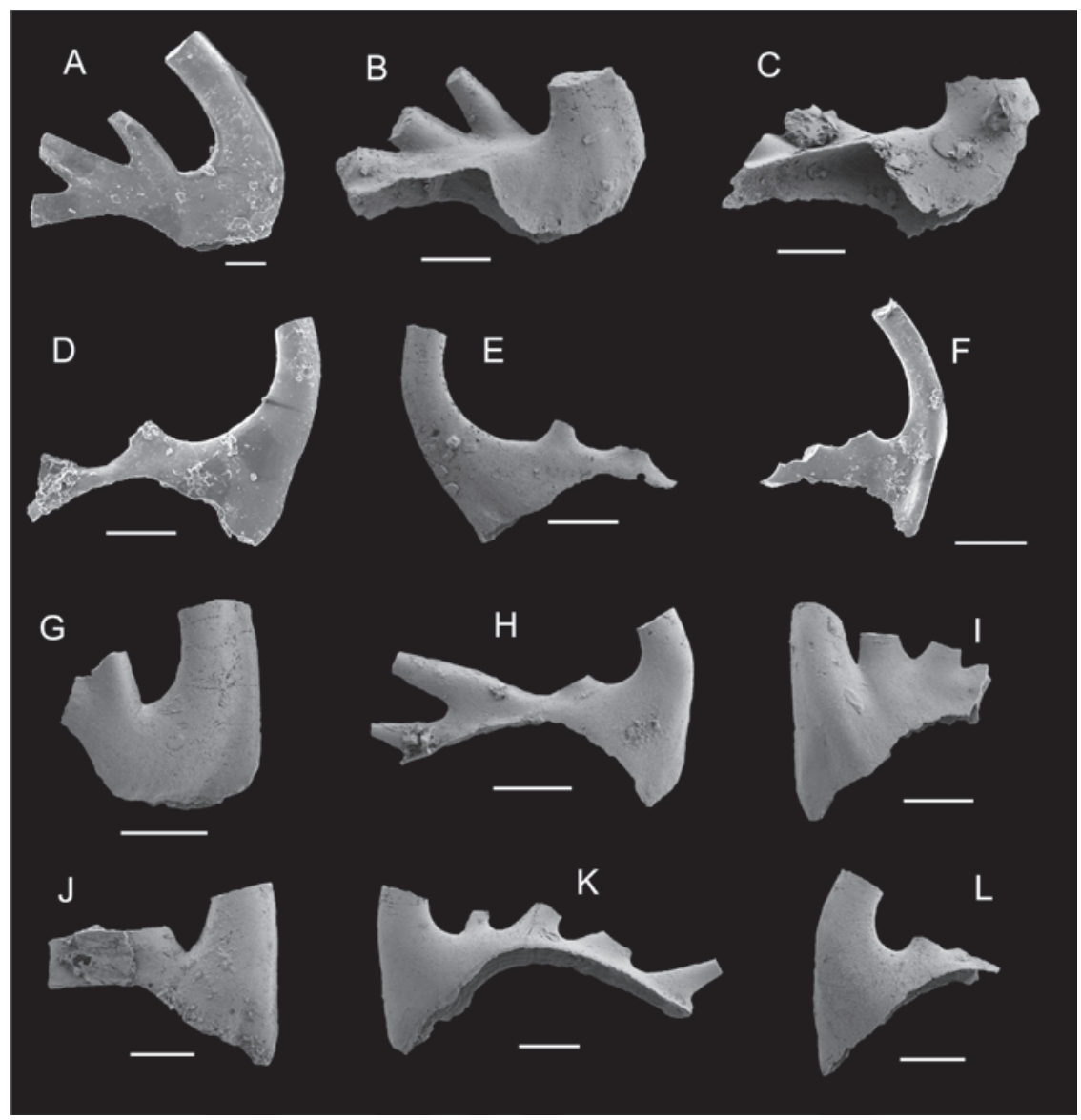

FIG. 4. Species of Cordylodus recovered from the Pantipampa locality, Iruya area, northwestern Argentina. A-G. Cordylodus angulatus Pander; A. Pa element, lateral view, CML-C 2000 (1); B-C. Pb elements, inner lateral views, CML-C 2001 (1-2); D-E. Sa elements, lateral views, CML-C 2002 (1-2); F. Sb element, inner lateral view, CML-C 2003 (1); G. fragment of Sc element, lateral view, CML-C 2018 (1). H. Cordylodus caseyi Druce and Jones, Sd element, lateral view, CML-C 2017 (1). I. Cordylodus lindstromi Druce and Jones, Sc element, lateral view, CML-C 2004 (1). J. fragment of Cordylodus hastatus Barnes, lateral view, CML-C 2004 (1). K-L. Cordylodus sp., lateral views, CML- C 2019 (1-2). Scale bars=100 $\mu \mathrm{m}$.

charge, attributed to a sedimentary cover ranging from 9,000 to 10,000 $\mathrm{m}$ in thickness (Epstein et al., 1977). Pressures of this magnitude are commonly associated with regional metamorphism which, in the case of the Iruya area, is of low-grade (Vilela, 1960).

\section{Systematic paleontology}

Systematic descriptions of euconodonts follow conventional notation (Sweet, 1981, 1988), which defines spatial positions of $\mathrm{M}, \mathrm{S}$ and $\mathrm{P}$, from the front end to the rear end of the multi-elemental apparatus.
Class Conodonta Pander, 1856

Order Paraconodontida Müller, 1962

Genus Furnishina Müller, 1959

Type species. Furnishina furnishi Müller, 1959.

Furnishina furnishi Müller, 1959

Fig. 5L

1959 Furnishina furnishi Müller, p. 452, pl. 11, figs. 5, 6, 9, 11-13, 15; fig. 6D.

1991 Furnishina furnishi. Müller and Hinz, p. 17-20, pl. 13, figs. 4, 12.

1999 Furnishina furnishi. Rao, p. 29-30, pl. 3, figs. $4,7$.

2015 Furnishina furnishi. Albanesi et al., p. 240, pl. 2, figs. 3, 11 . 


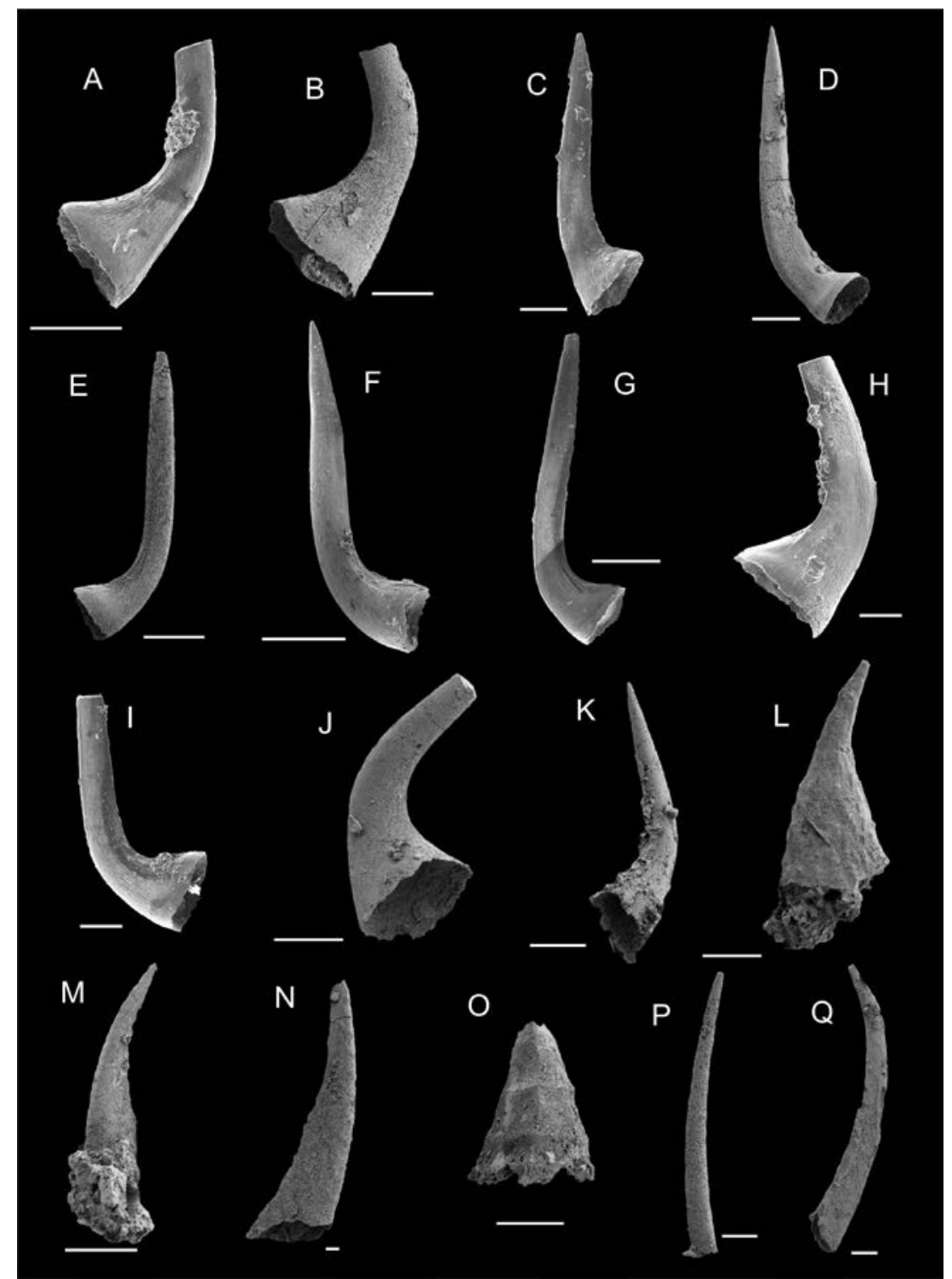

FIG. 5. Association of simple-cone elements recovered from the Pantipampa locality, Iruya area, northwestern Argentina. A-I. Semiacontiodus sp., possible apparatus; A-B. Pa elements, lateral views, CML-C 2020 (1-2); C. Pb element, lateral view, CML-C 2021 (1); D-E. Sa elements, lateral views, CMl-C 2022 (1-2); F. Sb element, lateral view, CML-C 2023 (1); G, Sc element, lateral view, CML-C 2024 (1); H-I. Sd elements, lateral views, CML-C 2025 (1-2); J-K. Teridontus nakamurai Nogami; J. Pa? element, latero-basal view, CML-C 2011 (1); K. Sd element, lateral view, CML-C 2015 (1); L. Furnishina furnishi Müller, lateral view, CMl-C 2006 (1); M-N. Proconodontus muelleri Miller, lateral views, CMl-C 2016 (1-2); O. Kallidontus gondwanicus Zeballo and Albanesi, antero-lateral view, CML-C 2009 (1); P. Phakelodus elongatus Zhang in An et al., lateral view, CM1-C 2007 (1); Q. Phakelodus tenuis Müller, lateral view, CML-C 2008 (1). Scale bars $=100 \mu \mathrm{m}$ except N=20 $\mu \mathrm{m}$.

Description. Simple cone element laterally compressed, with a thin, slightly reclined cusp. Element widens toward the base, which is broad and oval. The margins have well-marked ribs. Basal cavity broad and deep, occasionally filled. Outer surface with faint annulations.
Remarks. Albanesi et al. (2015) recognized two types of elements for this taxon: rounded ones and bilaterally compressed ones. In our collection from Pantipampa, only the bilaterally compressed elements have been found. 
Material. Three elements, CML-C 2006 (1-3). Occurrence. Pantipampa locality (Iruya area, northwestern Argentina), sample Pan 6*. Santa Rosita Formation, upper lower Tremadocian.

Genus Phakelodus Miller, 1984

Type species. Oneotodus tenuis Müller, 1959. Phakelodus elongatus (Zhang in An et al., 1983) Fig. 5P

1983 Proconodontus elongatus Zhang in An et al., p. 125, pl. 5, figs. 4-5.

1991 Phakelodus elongatus. Müller and Hinz, p. 32-33, pl. 1, figs. 1-5, 7-9, 12-14, 22 (cum syn.). 1999 Phakelodus elongatus. Rao, p. 30, pl. 1, figs. 1, 3, 4 .

2007 Phakelodus elongatus. Landing et al., fig. 6u. 2013 Phakelodus elongatus. Voldman et al., p. 317.

2015 Phakelodus elongatus. Albanesi et al., p. 241, Pl. 2, figs. 10, 17.

Description. Elongated and thin simple elements with some curvature toward inner side. Outer side slightly concave and inner side convex. Element cross section is rounded a short distance of the cusp, and it is spheroidal close to the base due to a delicate rib running through inner margin. Basal cavity deep. Element outer surface smooth.

Material. Six elements, CML-C 2007 (1-6).

Occurrence. Pantipampa locality (Iruya area, northwestern Argentina), sample Pan 6*. Santa Rosita Formation, upper lower Tremadocian.

Phakelodus tenuis (Müller, 1959)

Fig. 5Q

1959 Oneotodus tenuis Müller, p. 457, pl. 13, figs. 13, 14, 20.

1991 Phakelodus tenuis. Müller and Hinz, p. 33-34, pl. 1, figs. 6, 10-11, 15-21, 23, pl. 2 , figs. 1-24 (cum syn.).

1999 Phakelodus tenuis. Heredia, p. 353, fig. 6.F-G.

1999 Phakelodus tenuis. Rao, p. 30-32, pl. 1, fig. 5 (cum syn.).

2007 Phakelodus tenuis. Landing et al., fig. 6.s. 2013 Phakelodus tenuis. Voldman et al., p. 317-318, pl. 2, fig. 22.

2015 Phakelodus tenuis. Albanesi et al., p. 242, pl. 2, fig. 13.
Description. Element long and thin, flattened laterally. Inner and outer sides rounded. Cross section a short distance of cuspide rounded. Basal cavity deep. Elements with a smooth outer surface or with oblique ribs that form a fishbone structure on the posterior side.

Material. Eigth elements CML-C 2008 (1-8). Occurrence. Pantipampa locality (Iruya area, northwestern Argentina), sample Pan 6*. Santa Rosita Formation, upper lower Tremadocian.

Euconodonts

Orden Proconodontida Sweet, 1988

Family Cordylodontidae Lindström, 1970

Genus Cordylodus Pander, 1856

Type species. Cordylodus angulatus Pander, 1856

Discussion. Nicoll (1990) emended the diagnosis of this genus and identified six morphotypes in the structure of the apparatus; concepts that are followed herein.

\section{Cordylodus angulatus Pander, 1856 Fig. 4A-G}

1856 Cordylodus angulatus Pander, p. 33, pl. 2, figs. 28-31, pl. 3, fig. 10.

1856 Cordylodus rotundatus Pander, p. 33, pl. 2, figs. 32-33.

1990 Cordylodus angulatus. Nicoll, p. 536-543, fig. 3 (4a-c), 5-12 (cum syn.).

1999 Cordylodus angulatus. Rao, p. 34, pl. 8, figs. 7-10.

2005 Cordylodus angulatus. Zeballo et al., p. 3-4, fig. 3.G (cum syn).

2015 Cordylodus angulatus. Albanesi et al., p. 243, text-fig. $4(3,7)$.

Description. Although only a few elements were recovered from Pantipampa, they broadly agree with the description of Cordylodus angulatus provided by Nicoll (1990):

Pa element: Dolobrate ramiform element with recline cusp of oval cross section and sharp edges. The posterior process carries three long denticules with sharp edges, these denticules are located on the external margin of the process and are directed backwards, the cusp is twisted towards the inner face 
of the element. The base of the cuspid widens close to the union with the base forming a small platform that becomes thinner towards the end of the process. In an internal lateral view is evident one of the characteristics that defines the species, named by Lindström (1955) Phrygian cap. The basal margin is broad below the cusp and narrowed towards the process.

Pb element: Ramiform element, with reclined cusp of oval cross section and sharp edges. The posterior process carries three long denticules with sharp edges; these denticules are located on the external margin of the process. The denticules and the cusp are curved towards the inner side. The anterior margin of the basal cavity is concave; the small platform is less developed than in the element $\mathrm{Pa}$. The basal cavity is oval and extended along the element. The apex of the basal cavity reaches only the base of the cusp and is centrally located.

Sa element: Symmetrical elements laterally compressed with long cusp with rounded edges and sharply-edges. The outer margin of the cusp is concave and extends like a small keel beyond the basal cavity. The cusp is broad near its posterior end. The posterior process is thin and carries two denticles directed towards posterior, they are quite spaced apart. The basal cavity is wide below the cusp but it is slimming towards its anterior and posterior margins.

Sb element: Asymmetrical ramiform element. The cuspid is elongated and compressed of oval cross section, slightly curved towards interior, the anterior margin of the cusp is sharp and its basal part presents a rounded salient. The posterior process is long and carried out 4 to 6 denticles, which are located on the internal margin of the process. An inner lateral rib develops from the base of the cusp and extends laterally to form a protoprocess; this in conjunction with the posterior process and the basal margin give a triangular shape to the element.

Sc element: It is a fragment which is interpreted as a Sc element, and classified based on the anterior margin of the cusp which is keeled. This is an asymmetric element with an inwardly twisted cusp. The posterior process is fragmented but two denticles are evident.

No elements of the M and Sd morphotypes have been recovered.

Material. Two Pa elements CML-C 2000 (1-2), three $\mathrm{Pb}$ elements CML-C 2001 (1-3), two Sa elements CML-C 2002 (1-2), one Sb element CML-C 2003 (1), one fragment of Sc element CML-C 2018 (1) and two P elements CML-C 2019 (1-2).

Occurrence. Pantipampa locality (Iruya area, northwestern Argentina), sample Pan 6*. Santa Rosita Formation, upper lower Tremadocian.

\section{Cordylodus caseyi Druce and Jones, 1971} Fig. 4H

1971 Cordylodus caseyi Druce and Jones, p. 67-68, pl. 2, figs. 9-12; text-fig. 23d, e. 1990 Cordylodus caseyi. Nicoll, p. 543-545, figs. 3 (a-c), 13-15 (cum syn.).

1999 Cordylodus caseyi. Rao, p. 36, pl. 9, fig. 8. 2005 Cordylodus caseyi. Albanesi et al., fig. 7.J. 2007 Cordylodus caseyi. Landing et al., fig. 5.m-t.

Description. A single element collected from Pantipampa is regarded as a $\mathrm{Sb}$ element of the apparatus of Cordylodus caseyi (see Nicoll, 1990). The cusp is compressed with an oval cross section and sharp anterior and posterior margins; it is twisted with respect to the posterior process, and does not have ribs or carenas. Its anterior margin is projected on a small keel. The posterior process is long and arched carrying three large denticles directed towards posterior. The cavity tip is near the anterobasal corner.

Material. One Sb element, CML-C 2017 (1).

Occurrence. Pantipampa locality (Iruya area, northwestern Argentina), sample Pan 6*. Santa Rosita Formation, upper lower Tremadocian.

\section{Cordylodus hastatus Barnes, 1988}

Fig. 4J

1971 Cordylodus prion Lindström, Druce and Jones, p. 70, pl. 2, fig. 4.

1988 Cordylodus hastatus Barnes, p. 411, 412, figs. $13 \mathrm{~s}-\mathrm{x}, 14 \mathrm{~d}$ (cum syn.).

2005 Cordylodus hastatus. Albanesi et al., fig. 7A. 2013 Cordylodus hastatus. Giuliano et al., p. 40, fig. 3.31.

2015 Cordylodus hastatus. Albanesi et al., p. 243-244, pl. 3, fig. 4.

Description. Element robust, laterally compressed. The cusp is fragmented, proclined to erect with sharp flank. The anterior margin of the cusp ends in a small keel. The posterior process is also fragmented and 
shows two fused denticules at the base of the upper margin. The first denticule forms an angle of about $45^{\circ}$ with the posterior margin of the cusp.

Discussion. Compared with other recovered elements of Cordylodus, this element is proportionately large and has a high CAI value.

Material. One fragment, CML-C 2005 (1).

Occurrence. Pantipampa locality (Iruya area, northwestern Argentina), sample Pan 6*. Santa Rosita Formation, upper lower Tremadocian.

\section{Cordylodus lindstromi Druce and Jones, 1971} Fig. 4I

1971 Cordylodus lindstromi Druce and Jones, p. 68, text-fig. $23 \mathrm{~h}$, pl. 1, figs. 7-9, pl. 2, fig. 8. 1994 Cordylodus lindstromi. Ji and Barnes, p. 32, pl. 5, figs. 19-22 (cum syn.).

2005 Cordylodus lindstromi. Albanesi et al., fig. 7.H, K.

2015 Cordylodus lindstromi. Albanesi et al., p. 244, pl. 3, figs. 13, 17-20, Text-figs. 4, 1-2.

Description. The recovered element corresponds to the morphotype Sc described by Nicoll (1990), characterized by having a basal cavity (biapical) which extends into the first denticle of the posterior process. Element asymmetric, with inner side flattened and outer side convex. The cusp is broken and slightly twisted to the inner side; margin of cusp keeled, with its inner side extended on an inner lateral protoprocess, and the outer side with a delicate rib. Posterior process slightly arched, carrying three denticles of which the first is very close to the inner face of the cusp.

Discussion. This element differs from Cordylodus prolindstromi because the latter exhibits a truncate second basal cavity.

Material. One Sc element, CML-C 2004 (1).

Occurrence. Pantipampa locality (Iruya area, northwestern Argentina), sample Pan 6*. Santa Rosita Formation, upper lower Tremadocian.

Family Fryxellodontidae Miller, 1980 Genus Kallidontus Pyle and Barnes, 2002 Type species. Kallidontus serratus Pyle and Barnes, 2002

Kallidontus gondwanicus Zeballo and Albanesi, 2013

Fig. 50
?1999 Distacodus sp. Rao, p. 29, pl. 2, figs. 5-6. 1999 Muellerodus? cf. hunjiangensis Chen and

Gong. Albanesi et al., p. 524, fig. 5.

2005 Coelocerodontus sp. Zeballo et al., p. 50, 52, fig. 4.AH.

2013 Kallidontus gondwanicus Zeballo and Albanesi, p. 175-177, figs. 7V-Z, 9AC-AH. 2013 Kallidontus gondwanicus. Voldman et al., p. 314-315, pl. 2, figs. 2-4.

Description. Cusp small, subtriangular as the general form of the element, with three sharp lateral keels; posterior side slightly concave and anterior side convex. Basal cavity excavated. The main characteristic of this species is the presence of equidistant rings that are parallel to the base of the element.

Discussion. Although the recovered elements are very small and not well preserved, they accord with the $\mathrm{Pb}$ element of Kallidontus gondwanicus (see Voldman et al., 2013, p. 314-315).

Material. Three P elements, CML-C 2009 (1-3). Occurrence. Pantipampa locality (Iruya area, northwestern Argentina), sample Pan 6*. Santa Rosita Formation, upper lower Tremadocian.

Order Proconodontida Sweet, 1988 Superfamily Distacodontacea Bassler, 1925 Family Proconodontidae Lindström, 1970

Genus Proconodontus Miller, 1969

Type species. Proconodontus muelleri Miller, 1969

Proconodontus muelleri Miller, 1969 Fig. 5M-N

1969 Proconodontus muelleri muelleri Miller, p. 437 , pl. 66 , figs. $34-40$, fig. 5 h, non pl. 66 , figs. 31?, 32, 33.

1980 Proconodontus muelleri. Miller, p. 2931, pl. 1, fig. 7, text-fig. 4C.

1991 Proconodontus muelleri. Müller and Hinz, p. 56, pl. 42, figs. 1, 3-9, non pl. 42, figs. 2?,10?, 11, 14, 15, 16? (cum syn.).

1998 Proconodontus muelleri. Szaniawski and

Bengtson, p. 17, pl. 2, figs. 4-17, fig. 4.g-k. 2002 Proconodontus muelleri. Pyle and Barnes, p. 57, pl. 12, figs. 21-22.

2016 Proconodontus muelleri. Jahangir et al., p. 234, fig. 4.A-B. 
Description. Szaniawsky and Bengtson (1998) described the apparatus of Proconodontus muelleri as containing three elemental morphotypes. In our collection from Pantipampa, only compressed simple cone elements were recognized. They are laterally compressed with sharp, keeled anterior and posterior margins and smooth lateral faces. Anterior side slightly convex and posterior side concave. Cusp reclined to recurved. Basal cavity deep, reaching tip of the cusp. Base with oval cross section. An oblique striation can be observed along the element. Material. Three elements, CML-C 2021(1-3).

Discussion. As stated above, the nearly geniculate and rounded specimens reported for Proconodontus muelleri (Szaniawsky and Bengtson, 1998) were not recovered from the sample studied.

Occurrence. Pantipampa locality (Iruya area, northwestern Argentina), sample Pan 6*. Santa Rosita Formation, upper lower Tremadocian.

\section{Order Protopanderodontida Sweet, 1988}

Family Scolopondidae Bergström, 1981

Genus Semiacontiodus Miller, 1969

Type species. Acontiodus (Semiacontiodus) nogamii Miller, 1969. Semiacontiodus sp.

Fig. 5A-I

cf. 2005 Semiacontiodus striatus Zeballo et al., p. 58, fig. 4.u, v, $x$.

Description. Simple cone element robust, with long cuspid and short base in relation to the length of the cusp. Cusp straight, reclined or slightly curved posteriorly, laterally compressed, with sharp edges. Element surface microstriated (except basal margin, which is smooth and thick-walled). The number of ribs is variable; in some elements, a strong lateral rib that runs throughout the cusp causes torsion towards the inner side, giving the element a strong asymmetry; other 2 or 3 small ribs are present on the inner face, between the base and the beginning of the cusp.

Discussion. Based on the reconstruction of the apparatus of Semiacontiodus cornuformis provided by Löfgren (1999), the elements recovered from Pantipampa are regarded as two $\mathrm{P}$ elements ( $\mathrm{Pa}$ and $\mathrm{Pb}$ ) which present a short basal cavity with a wide and wavy basal margin. The material studied mostly resembles $S$. striatus Zeballo et al. (2005), from the Lower Ordovician (Cordylodus angulatus Zone) of the Cordillera Oriental, although the former seems to have a stronger ornamentation.

Material. six hundred ninety-eight (698) elements CML-C 2020 (1-698).

Occurrence. Pantipampa locality (Iruya area, northwestern Argentina), samples Pan 6* and 6'. Santa Rosita Formation, upper lower Tremadocian.

Incertae Familiae

Genus Teridontus Miller, 1980

Type species. Oneotodus nakamurai Nogami, 1967

Teridontus nakamurai (Nogami, 1967)

Fig. 5J-K

1967 Oneotodus nakamurai Nogami, p. 216-217, pl. 1, figs. 9, 12, text-fig. 3.A, B.

1980 “Oneotodus" nakamurai. Landing et al., p. 28-31, fig. 8 A-C (cum syn).

1994 Teridontus nakamurai. Ji and Barnes, p. 64-65, pl. 24, figs. 1-9, text.-fig. 37.C (cum syn). 1994 Teridontus nakamurai. Nicoll, p. 371-377, figs. 3-15 (cum syn).

2002 Teridontus nakamurai. Pyle and Barnes, p. 71, pl. 15, figs. 17-19.

Description. The recovered elements agree with the description of T. nakamurai provided by Nicoll (1994). The P and S elements were compared with those illustrated by this author and classified mainly in terms of the basal contour and the length of the basal cavity. Cusps have diverse inclinations. Elements lack grooves, keels and carinae. Fine striations have been noted on the surface of well-preserved specimens, although they are absent near the basal margin. The distribution of white matter could not be observed due to a high CAI degree (4-5).

Material. Fourty elements CML-C 2010(1-40). Distributed in $22 \mathrm{P}$ elements and $18 \mathrm{~S}$ elements.

Occurrence. Pantipampa locality (Iruya area, northwestern Argentina), samples Pan 6* and 6'. Santa Rosita Formation, upper lower Tremadocian.

\section{Biostratigraphic and paleoenvironmantal implications}

Conodonts from the Santa Rosita Formation of Pantipampa include Cordylodus angulatus, C. caseyi, C. lindstromi, C. hastatus, Furnishina furnishi, 
Kallidontus gondwanicus, Phakelodus elongatus, Phakelodus tenuis, Proconodontus muelleri, Semiacontiodus sp. and Teridontus nakamurai. Although this fauna is low-diverse, Cordylodus angulatus is a biostratigraphically important species that characterizes the upper lower Tremadocian eponymous zone. Cordylodus angulatus has been reported from both the Atlantic and the Midcontinent Realm (e.g., Ji and Barnes, 1994; Löfgren, 1997). The geographic distribution of the C. angulatus Zone is truly wide, including Mexico (Robison and Pantoja-Alor, 1968; Repetski, 1982), USA (Orndoff, 1988; Harris et al., 1995), Canada (Nowlan, 1985; Bagnoli et al., 1987; Ji and Barnes, 1994), Russia (Pander, 1856), Sweden (Lindström, 1971; Van Wamel, 1974; Löfgren, 1996), Australia (Druce and Jones, 1971; Nicoll, 1990), Iran (Müller, 1973) and China (An, 1987).

In addition, this zone has been reported from several localities of the Argentinian Cordillera Oriental (e.g., see compilations of Albanesi and Ortega, 2016; Ortega and Albanesi, 2005; Zeballo and Albanesi, 2007, 2013; Albanesi et al., 2008; Zeballo et al., 2008). Conodont assemblages are relatively diverse and comprise a high percentage of endemic species such as Acanthodus raqueli, Kallidontus gondwanicus and Variabiloconus crassus (Zeballo and Albanesi, 2007, 2013). Well-constrained sections of the Santa Rosita Formation and equivalents include Sierra de Cajas (Hünicken et al., 1985; Rao and Hünicken, 1995; Rao, 1999; Albanesi et al., 2015), El Perchel area (Zeballo et al., 2011), Alfarcito (Zeballo et al., 2005; Zeballo and Albanesi, 2013), Angosto del Moreno (Moya and Albanesi, 2000; Moya et al., 2003), Angosto de La Quesera (Carlorosi et al., 2011) and the Incamayo area (Rao and Tortello, 1998; Tortello and Rao, 2000). Besides, the C. angulatus Zone also occurs in the Famatina Range (Volcancito Formation) (Albanesi et al., 1999) and the Precordillera of San Juan (La Silla Formation) (Lehnert, 1995).

Conodonts from Pantipampa come from two levels that are assignable to the uppermost part of the trilobite Kainella meridionalis Zone sensu Vaccari et al. (2010) and the lowest part of the K. teiichii Zone Vaccari et al. (2010), respectively (Tortello and Esteban, 2016). In the former level, the trilobite assemblage is composed of Kainella meridionalis Kobayashi, 1935, Leptoplastides marianus (Hoek in Steinmann and Hoek, 1912) (=Andesaspis argentinensis Kobayashi, 1935) and Asaphellus catamarcensis Kobayashi, 1935, whereas the upper level contains the index species $K$. teiichii Vaccari and Waisfeld, 2010 in association with diverse olenids, asaphids, ceratopygids, richardsonellids, nileids, shumardids, hapalopleurids and agnostoids (Tortello and Esteban, 2016). Other occurrences of conodonts of the $C$. angulatus Zone associated with Kainella, Leptoplastides marianus and Asaphellus catamarcensis were previously reported from the Incamayo area (Rao and Tortello, 1998; Tortello and Rao, 2000; Albanesi et al., 2008). Similarly, a correspondence between the C. angulatus and the "Kainella zones" were also indicated by Zeballo et al. (2011) for the Alfarcito region.

Analysis of the taxonomic diversity and relative frequency of conodont species from Pantipampa reveals that Semiacontiodus sp. (61.5\%) largely dominates the assemblages, followed far behind by Teridontus nakamurai (4.53\%) and Cordylodus angulatus $(1.13 \%)$, while indeterminate fragments $(8.84 \%)$ and remaining species represent a very low percentage of the total fauna. This enables the recognition of the Semiacontiodus-Teridontus community, which is characteristic of shallow marine environments (Ji and Barnes, 1994; Löfgren, 1999). According to Tortello and Esteban (2016) and Esteban et al. (2017), the Pantipampa section represents a storm- and wave-dominated shelf. The conodont samples were recovered from Facies 3, which reflects sedimentation above storm wave base and moderately high-energy conditions.

\section{Conclusions}

Based on its conodont faunas, a part of the Santa Rosita Formation in Pantipampa is assigned to the upper lower Tremadocian Cordylodus angulatus Zone and correlated with other localities of the Cordillera Oriental and the world. In the studied area, the C. angulatus Zone is partially equivalent to the trilobite Kainella meridionalis Zone (uppermost part) and the Kainella teiichii Zone (lowest part). Taxonomic diversity and relative frequency of conodont species enables the recognition of the Semiacontiodus-Teridontus community, which is characteristic of shallow marine environments.

\section{Acknowledgments}

We are grateful to E. Gómez Hasselrot and M. del Huerto Benítez for their help during field work. S. Heredia provided 
helpful comments on an early version of the manuscript. In addition, M. Ghobadi Pour and an anonymous referee are thanked for their constructive remarks on the submitted manuscript. This research was supported by the Consejo Nacional de Investigaciones Científicas y Técnicas, the Instituto Superior de Correlación Geológica (CONICETUniversidad Nacional de Tucumán), and the Universidad Nacional de La Plata, Argentina.

\section{References}

Albanesi, G.L.; Ortega, G. 2016. Conodont and Graptolite Biostratigraphy of the Ordovician System of Argentina. In Stratigraphy and Timescales (Montenari, M.; editor). Elsevier Inc.: 61-121.

Albanesi, G.L.; Esteban, S.B.; Barnes, C.R. 1999. Conodontes del intervalo del límite Cámbrico-Ordovícico en la Formación Volcancito, Sistema de Famatina, Argentina. Temas Geológico-Mineros 26: 521-526.

Albanesi, G.L.; Esteban, S.B.; Ortega, G.; Hünicken, M.A.; Barnes, C.R. 2005. Bioestratigrafía y ambientes sedimentarios de las formaciones Volcancito y Bordo Atravesado (Cámbrico Superior-Ordovícico Inferior), Sistema de Famatina, provincia de La Rioja, Argentina. In Geología de la provincia de La Rioja: PrecámbricoPaleozoico inferior (Dahlquist, J.A.; Baldo, E.G.; Alasino, P.H.; editors). Asociación Geológica Argentina, Serie D, Publicación especial 8: 41-64.

Albanesi, G.L.; Ortega, G.; Zeballo F.J. 2008. Faunas de conodontes y graptolitos del Paleozoico Inferior en la Cordillera Oriental Argentina. In Congreso Geológico Argentino, No. 17, Relatorio 2: 98-118. Jujuy.

Albanesi, G.L.; Giuliano, M.E.; Pacheco, F.; Ortega, G.; Monaldi, C.R. 2015. Conodonts from the CambrianOrdovician boundary in the Cordillera Oriental, NW Argentina. Stratigraphy 12 (3-4): 237-256.

An, T. 1987. The Lower Paleozoic conodonts of South China. Peking University, Publication House, Beijing: 1-238.

An, T.-X.; Zhang, F.; Xiang,W.; Zhang, Y.; Xu,W.; Zhang, H.; Jiang, D.;Yang, C. Lin;Y.-K.; Cui, Z.; Yang, X. 1983. The conodonts of North China and the adjacent regions. Science Press: 223 p. Beijing.

Astini, R.A. 2003. The Ordovician Proto-Andean Basins. In Ordovician fossils of Argentina (Benedetto, J.L.; editor). Universidad Nacional de Córdoba, Secretaría de Ciencia y Tecnología: 1-74.

Bagnoli, G.; Barnes, C.R.; Stevens, R.K. 1987. Lower Ordovician (Tremadocian) conodonts from Broom Point and Green Point, Western Newfoundland. Bollettino della Società Paleontologica Italiana 25 (2): 145-158.
Barnes, C.R. 1988. The proposed Cambrian-Ordovician global boundary stratotype and point (GSSP) in western Newfoundland, Canada. Geological Magazine 125 (4): 381-414.

Bassler, R.S. 1925. Classification and stratigraphic use of the conodonts. Geological Society of America Bulletin 36: 218-220.

Bergström, S.M. 1981. Family scolopondidae. In Treatise on invertebrate paleontology (Robison, R.A.; editor). University of Kansas Press, Part W, Supplement 2: W141. Conodonta.

Buatois, L.A.; Mángano, M.G. 2003. Sedimentary facies, depositional evolution of the Upper Cambrian-Lower Ordovician Santa Rosita formation in northwest Argentina. Journal of South American Earth Sciences 16: 343-363.

Buatois, L.A.; Zeballo, F.J.; Albanesi, G.L.; Ortega, G.; Vaccari, N.E.; Mángano, M.G. 2006. Depositional environments and stratigraphy of the upper Cambrianlower Ordovician Santa Rosita Formation at the Alfarcito area, Cordillera Oriental, Argentina: integration of biostratigraphic data within a sequence stratigraphic framework. Latin American Journal of Sedimentology and Basin Analysis 13: 1-29.

Carlorosi, J.; Heredia, S.; Aceñolaza, G. 2011. Ordovician Conodonts of the Devendeus Formation at the Angosto de la Quesera (Salta Eastern Cordillera): Taxonomic Considerations and Biostratigraphic Significance. Geologica Acta 9 (2): 187-197.

Druce, E.C.; Jones, P.J. 1971. Cambro-Ordovician conodonts from the Burke River Structural Belt, Queensland. Bureau of Mineral Resources, Geology and Geophysics Bulletin 110: 1-159.

Eichwald, E.J. 1855. Beitrag zur geographischen Verbreitung der fossilen Thiere Russlands. Alte Periode. Bulletin de la Societé Imperiale des Naturalistes de Moscou, 28: 433-466.

Epstein, A.G.; Epstein, J.P.; Harris, L. 1977. Conodont Alteration-An Index to Organic Metamorphism. United States Geological Survey Professional Paper 995: 1-27.

Esteban, S.B.; Benítez, M.H.; Tortello, M.F. 2016. Geología sedimentaria y paleoambientes de la Formación Santa Rosita (Ordovícico Temprano) en la región de Nazareno, Cordillera Oriental, provincia de Salta, Argentina. Serie Correlación Geológica 31 (1): 5-20.

Esteban, S.B.; Benítez, M.H.; Tortello, M.F. 2017. Sedimentología y tafonomía de la Formación Santa Rosita en la región de Pantipampa-Rodeo Colorado (Departamento Iruya, provincia de Salta). In Congreso Geológico Argentino, No. 20 y Simposio de Estratigrafía 
y Paleontología del Paleozoico Inferior de Argentina, Actas: 29-31. Tucumán.

Figueroa-Caprini, M. 1955. Contribución al conocimiento geológico y petrográfico de la zona comprendida entre San Pedro de Iruya y el cerro Minero, provincia de Salta. Ph.D. Thesis (Inédito), Facultad de Ciencias Naturales y Museo, Universidad Nacional de La Plata: 75 p.

Giuliano, M.E.; Albanesi, G.L.; Ortega, G.; Zeballo, F.J.; Monaldi, C.R. 2013. Conodonts and graptolites of the Santa Rosita Formation (Tremadocian) at the Nazareno area, Santa Victoria Range, Cordillera Oriental of Salta, Argentina. In Conodonts from the Andes (Albanesi, G.L.; Ortega, G.; editors), Proceedings of the International Conodont Symposium, No. 3, and Regional Field Meeting of the IGCP project 591. Asociación Paleontológica Argentina, Publicación Especial 13: 39-44..

Harrington, H.J.; Leanza, A.F. 1957. Ordovician trilobites of Argentina. University of Kansas, Department of Geology, Special Publication 1: 276 p.

Harris, A.G.; Repetski, J.E.; Stamm, N.R.; Weary, D.J. 1995. Conodont age and CAI data for New Jersey. United States Department of the Interior and United States Geological Survey, Open file report 95-557: 1-31.

Heredia, S. 1999. Los paraconodontes del Cámbrico Superior del cerro Pelado, Precordillera de Mendoza, Argentina. Ameghiniana 36: 345-358.

Hünicken, M.; Suárez Riglos, M.; Sarmiento, G. 1985. Conodontes tremadocianos de la sierra de Cajas, Departamento Humahuaca, Provincia de Jujuy. Boletín de la Academia Nacional de Ciencias de Córdoba 56 (3-4): 333-347.

Jahangir, H.; Ghobadi Pour, M.; Ashuri, A.; Amini, A. 2016. Terminal Cambrian and Early Ordovician (Tremadocian) conodonts from Eastern Alborz, northcentral Iran. Alcheringa 40 (2): 219-243.

Ji, Z.; Barnes, C.R. 1994. Lower Ordovician conodonts of the St. George Group, Port au Port Peninsula, western Newfoundland, Canada. Palaeontographica Canadiana 11: 1-149.

Kobayashi, T. 1935. On the Kainella Fauna of the Basal Ordovician Age Found in Argentina: Japanese Journal of Geology and Geography 12: 59-67.

Landing, E.; Ludvigsen, R.; Vonbitter, P.H. 1980. Upper Cambrian to Lower Ordovician conodont biostratigraphy and biofacies, Rabbitkettle Formation, District of Mackenzie. Life Sciences Contribution, Royal Ontario Museum 126: 1-42.

Landing, E.; Westrop, S.R.; Keppie, J.D. 2007. Terminal Cambrian and lowest Ordovician succession of Mexican West Gondwana: biotas and sequence stratigraphy of the Tiñu Formation. Geological Magazine 144 (6): 909-936.

Lehnert, O. 1995. The Tremadoc/Arenig transition in the Argentine Precordillera. In Ordovician Odyssey (Cooper, J.D.; Droser, M.L.; Finney, S.C.; editors), Short Papers for the Seventh International Symposium on the Ordovician System, SEPM, Fullerton: 145-148. Las Vegas.

Lindström, M. 1955. Conodonts from the lowermost Ordovician strata of south-central Sweden. Geologiska Föreningens i Stockholm Förhandlingar 76 (21): 517-604.

Lindström, M. 1970. A suprageneric classification of the conodonts. Lethaia 3: 427-445.

Lindström, M. 1971. Lower Ordovician conodonts of Europe. Geological Society of America Memoir (Sweet, W.C.; Bergström, S.M.; editors) 127: 21-61.

Löfgren, A. 1996. Lower Ordovician conodonts, reworking, and biostratigraphy of the Orreholmen quarry, Västergötland, south-central Sweden. Geologiska Föreningens i Stockholm Förhandlingar 118: 169-183.

Löfgren, A. 1997. Conodont faunas from the upper Tremadoc at Brattefors, south-central Sweden, and reconstruction of the Paltodus apparatus. Geologiska Föreningens i Stockholm Förhandlingar 119: 257-266.

Löfgren, A. 1999. The Ordovician conodont Semiacontiodus cornuformis (Sergeeva, 1963) and related species. Geologica et Palaeontologica 33: 71-91.

Löfgren, A.; Viira, V.; Mens, K. 2005. Conodont biostratigraphy and sedimentary history in the upper Tremadoc at Uuga, Cape Pakri, NW Estonia. Geologiska Föreningens i Stockholm Förhandlingar 127: 283-293.

Miller, J.F. 1969. Conodont fauna of the Notch Peak Limestone (Cambro-Ordovician), House Range, Utah. Journal of Paleontology 43: 413-439.

Miller, J.F. 1980. Taxonomic revisions of some Upper Cambrian and Lower Ordovician conodonts with comments on their evolution. University of Kansas Paleontological Contributions 99: 1-44.

Miller, J.F. 1984. Cambrian and earliest Ordovician conodont evolution, biofacies, and provincialism. In Conodont Biofacies and Provincialism (Clark, D.L.; editor). Geological Society of America, Special Paper 196: 43-68.

Moya, M.C. 1988. Estratigrafía del Tremadociano en el tramo austral de la Cordillera Oriental. Tesis Doctoral (Inédito) Universidad Nacional de Salta, Facultad de Ciencias Naturales: 368 p.

Moya, M.C. 1999. El Ordovícico en los Andes del Norte Argentino (González-Bonorino, G.; Omarini, 
R.; Viramonte, J.; editors). In Congreso Geológico Argentino, No. 14, Relatorio 1: 134-152. Salta.

Moya, M.C.; Albanesi, G.L. 2000. New stratigraphic section to define the Cambrian- Ordovician boundary in Eastern Cordillera, northwestern Argentina. INSUGEO (Instituto Superior de Correlación Geológica), Miscelánea 6: 114-116.

Moya, M.C.; Malanca, S.; Monteros, J.A.; Albanesi, G.L.; Ortega, G.; Buatois, L. 2003. Late CambrianTremadocian faunas and events from Angosto del Moreno Section, Eastern Cordillera, Argentina. In Ordovician from the Andes (Albanesi, G.L.; Beresi, M.S.; Peralta, S.H.; editor). INSUGEO, Serie de Correlación Geológica 17: 439-444.

Müller, K.J. 1959. Kambrische conodonten. Zeitschrift der Deutschen Geologischen Gesellschaft 111: 434-485.

Müller, K.J. 1962. Supplement to systematics of conodonts. In Treatise on Invertebrate Paleontology (Moore, R.C.; editor). Geological Society of America and University of Kansas, Part W, Miscellanea: W246-W249. New York and Lawrence.

Müller, K. 1973. Late Cambrian and Early Ordovician conodonts from northern Iran. Reports of Geological Survey of Iran 30: 1-77.

Müller, K.J.; Hinz, I. 1991. Upper Cambrian conodonts from Sweden. Fossils and Strata 28: 1-153.

Nicoll, R.S. 1990. The genus Cordylodus and a latest Cambrian-earliest Ordovician conodont biostratigraphy. Journal of Australian Geology and Geophysics 11: 529-558.

Nicoll, R.S. 1994. Seximembrate apparatus structure of the Late Cambrian coniform conodont Teridontus nakamurai from the Chatsworth Limestone, Georgina Basin, Queensland. AGSO Journal of Australian Geology and Geophysics 15: 367-379.

Nogami, Y. 1967. Kambrische Conodonten von China, Teil 2: Conodonten aus den hoch oberkambrischen Yencho-Schichten. Memoirs of the College of Science, University of Kyoto, Geology and Mineralogy, Series B 33 (4): 211-219.

Nowlan, G.S. 1985. Late Cambrian and Early Ordovician conodonts from the Franklinian Miogeosyncline, Canadian Arctic Islands. Journal of Paleontology 59: 96-122.

Nowlan, G.S.; Barnes, C.R. 1987. Thermanl maturation of Paleozoic strata in eastern Canada from conodont colour alteration index (C.A.I) data with implications for burial history, tectonic evolution, hotspot tracksand mineral and hidrotermal potential. Geological Survey of Canada Bulletin 367: 1-47.
Orndorff, R.C. 1988. Latest Cambrian and Earliest Ordovician conodonts from the Conococheague and Stonehenge limestones of northwestern Virginia. Bulletin of the United States Geological Survey 1837A: 1-18.

Ortega, G.; Albanesi, G.L. 2005. Tremadocian GraptoliteConodont Biostratigraphy of the South American Gondwana margin (Eastern Cordillera, NW Argentina). Geologica Acta 3 (4): 355-371.

Pander, C.H. 1856. Monographie der fossilen Fische des silurischen Systems der russisch-baltischen Gouvernements. Akademie der Wissenschaften: $91 \mathrm{p}$.

Pyle, L.; Barnes, C.R. 2002. Taxonomy, evolution, and biostratigraphy of conodonts from the Kechika Formation, Skoki Formation, and Road River Group (Upper Cambrian to Lower Silurian), Northeastern British Columbia. NRC Research Council of Canada: 227 p. Ottawa.

Ramos, V.A. 1999. Las provincias geológicas del territorio argentino. In Geología Argentina (Caminos, R.; editor). Instituto de Geología y Recursos Minerales, Anales 29 (3): 41-96. Buenos Aires.

Ramos, V.A. 2008. The basement of the Central Andes: The Arequipa and Related Terranes. Annual Review of Earth and Planetary Sciences 36: 289-324.

Rao, R.I. 1999. Los conodontes cambro-ordovícicos de la Sierra de Cajas y del Espinazo del Diablo, Cordillera Oriental, República Argentina. Revista Española de Micropaleontología 31 (1): 23-51.

Rao, R.I.; Hünicken, M. 1995. Conodontes del Cámbrico Superior - Ordovícico Inferior en el área de Purmamarca, Cordillera Oriental, Provincia de Jujuy, República de Argentina. Boletín de la Academia Nacional de Ciencias 60 (3-4): 249-266. Córdoba.

Rao, I.R.; Tortello, M.F. 1998. Tremadoc conodonts and trilobites from the Cardonal Formation, Incamayo Creek, Salta Province, northwestern Argentina. Palaeontologia Polonica 58: 31-45.

Rejebian, V.A.; Harris, A.G.; Huebner, J.S. 1987. Conodonts colour and texture alteration: An index to regional metamorphism, contact metamotphism, and hydrothermal alteration. Geological Society of American Bulletin 99: 471-479.

Repetski, J.E. 1982. Conodonts from El Paso Group (Lower Ordovician) of the westernmost Texas and southern New Mexico. New Mexico Bureau of Mines and Mineral Resources, Memoir 40: 1-121.

Robison, R.A.; Pantoja-Alor, J. 1968. Tremadocian trilobites from Nochixtlan region, Oaxaca, Mexico. Journal of Paleontology 42: 767-800. 
Steinmann, G.; Hoek, H. 1912. Das Silur und Cambrian des Hochlandes von Bolivia und ihre fauna. Neues Jahrbuch für Mineralogie, Geologie und Paläontologie 34: 176-252.

Stone, J. 1987. Review of investigative techniques used in the study ofconodonts. In Conodonts: Investigative techniques and applications (Austin, R.L.; editor). Chichester, Ellis Horwood Limited: 17-34.

Sweet, W.C. 1981. Macromorphology of elements and apparatuses. In Treatise on Invertebrate Paleontology, Part W, Miscellanea, Supplement 2, Conodonta, Lawrence, Kansas (Robison, R. A.; editors), Geological Society of America and University of Kansas Press: W5-W20.

Sweet, W.C. 1988. The Conodonta: Morphology, Taxonomy, Paleoecology, and evolutionary history of a long-extinct animal phylum. Oxford Monographs on Geology and Geophysics 10: 212 p. Clarendon Press, New York.

Szaniawski, H.; Bengtson, S. 1998. Late Cambrian euconodonts from Sweden. Palaeontologia Polonica 58: 7-29.

Tortello, M.F.; Rao, R.I. 2000. Trilobites y conodontes del Ordovícico Temprano del Angosto de Lampazar (provincia de Salta, Argentina). Boletín Geológico y Minero 111: 61-84.

Tortello, M.F.; Esteban, S.B. 2016. Early Ordovician trilobites from the Iruya area (Cordillera Oriental, northwestern Argentina) and their stratigraphic significance. Journal of Paleontology 90: 923-958.

Turner, J.C. 1959. Estratigrafía del cordón de Escaya y de la sierra de Rinconada (Jujuy). Revista de la Asociación Geológica Argentina 13 (1-2): 15-39.

Turner, J.C. 1960. Estratigrafía de la Sierra de Santa Victoria y adyacencias. Boletín de la Academia Nacional de Ciencias 41 (2): 163-196. Córdoba.

Turner, J.C. 1964. Descripción geológica de la hoja 2c, Santa Victoria (provincias de Salta y Jujuy). Instituto Nacional de Geología y Minería, Boletín 104: 1-83.

Turner, J.C.; Mon, R. 1979. Cordillera Oriental. In Geología Regional Argentina (Turner, J.C.; editor). Academia Nacional de Ciencias de Córdoba 1: 57-94.

Vaccari, N.E.; Waisfeld, B.G. 2010. Kainella Walcott, 1925 (Trilobita, Ordovícico Temprano) en el noroeste de Argentina y sur de Bolivia. Paleontología sistemática. Ameghiniana 47: 273-292.

Vaccari, N.E.; Waisfeld, B.G.; Marengo, L.F.; Smith, L.G. 2010. Kainella Walcott, 1925 (Trilobita, Ordovícico Temprano) en el noroeste de Argentina y sur de Bolivia. Importancia bioestratigráfica. Ameghiniana 47: 293-305.
Viira, V.; Mens, K.; Nemliher, J. 2006. Lower Ordovician Leetse Formation in the North Estonian Klint area. Proceedings of the Estonian Academy of Sciences, Geology 55: 156-174.

Vilela, C.R. 1960. Algunos rasgos particulares de la geología de Iruya (Salta-Jujuy). Revista de la Asociación Geológica Argentina 15: 119-144.

Waisfeld, B.G.; Vaccari, N.E. 2008. Bioestratigrafía de trilobites del Paleozoico inferior de la Cordillera Oriental. In Geología y Recursos Naturales de la Provincia de Jujuy (Coira, B.; Zappettini, E.O.; editors). Relatorio del Congreso Geológico Argentino, No 17: 119-127. Jujuy.

Van Wamel, W.A. 1974. Conodont biostratigraphy of the Upper Cambrian and Lower Ordovician of north-western Öland, south-eastern Sweden. Utrecht Micropalaeontological Bulletin 10: 1-125.

Voldman, G.G.; Albanesi, G.L.; Zeballo, F.J.; Monaldi, C.R. 2013. Early Ordovician (late Floian) conodonts from the Zenta range, Cordillera Oriental, NW Argentina. In Conodonts from the Andes (Albanesi, G.L.; Ortega, G.; editors). Proceedings of the International Conodont Symposium, No 3, Paleontological Note PE APA: 123-128. Mendoza.

Zeballo, F.J.; Albanesi, G.L. 2007. Revisión de la Zona de Cordylodus angulatus en el margen este de la Cordillera Oriental argentina. Ameghiniana 44 (4): 101-102R.

Zeballo, F.J.; Albanesi, G.L. 2013. New conodont species and biostratigraphy of the Santa Rosita Formation (late Furongian-Tremadocian) in the Tilcara range, Cordillera Oriental of Jujuy, Argentina. Geological Journal 48: 170-193.

Zeballo, F.J.; Albanesi, G.L; Ortega, G. 2005. Conodontes y graptolitos de las formaciones Alfarcito y Rupasca (Tremadociano) en el área de Alfarcito, Tilcara, Cordillera Oriental de Jujuy, Argentina, Parte 2: Paleontología sistemática. Ameghiniana 42: 47-66.

Zeballo, F.J.; Albanesi, G.L.; Ortega, G. 2008. New records of late Tremadocian (early Ordovician) conodonts and graptolites from the eastern Cordillera, Jujuy province, Argentina. Geologica Acta 6 (2): 131-145.

Zeballo, F.J.; Albanesi, G.L.; Ortega, G. 2011. Biostratigraphy and paleoenvironments of the Santa Rosita Formation (Late Furongian-Tremadocian), Cordillera Oriental of Jujuy, Argentina. In Ordovician of the World (Gutiérrez-Marco, J.C.; Rábano, I.; GarcíaBellido, D.; editors). Instituto Geológico y Minero de España, Cuadernos del Museo Geominero 14: 625-632. 